\title{
PEMBELAJARAN DARING KOMBINASI BERBASIS WHATSAPP PADA KELAS KARYAWAN PRODI TEKNIK INFORMATIKA UNIVERSITAS PGRI MADIUN
}

\author{
Latjuba Sofyana ${ }^{1}$, Abdul Rozaq ${ }^{2}$ \\ ${ }^{1}$ Teknik Informatika,Universitas PGRI Madiun, Madiun, Indonesia \\ ${ }^{2}$ Teknik Informatika,Universitas PGRI Madiun, Madiun, Indonesia \\ e-mail: latjubastt@unipma.ac.id', zarozaq@gmail.com ${ }^{2}$
}

\begin{abstract}
Abstrak
Perkembangan pendidikan tinggi saat ini dipengaruhi oleh pesatnya kemajuan teknologi informasi dan komunikasi. Salah satu teknologi informasi yang ikut berperan dalam dunia pendidikan adalah pembelajaran Daring. Pembelajaran daring berfungsi sebagai penghubung antar dosen dan mahasiswa dengan jaringan internet yang dapat diakses kapan saja dan dimana saja. Tujuan dari penelitian ini adalah menganalisis penerapan pembelajaran Daring Kombinasi berbasis whatsapp pada kelas karyawan Prodi Teknik Informatika, Universitas PGRI Madiun. Metode penelitian ini menggunakan metode pengumpulan data, Instrumen yang digunakan menggunakan kuesioner dalam bentuk daftar pertanyaan yang ditujukan kepada mahasiswa kelas karyawan. Hasil dari penelitian disimpulkan bahwa 69\% menyatakan kurang efektif pembelajaran secara konvensional, minat mahasiswa dalam pembelajaran daring sekitar $89 \%$ berminat dan $78 \%$ setuju bahwa dalam penerapannya dinilai lebih efektif daripada pembelajaran konvensional.
\end{abstract}

Kata kunci: Daring, model pembelajaran, mahasiswa

\begin{abstract}
The development of higher education is currently influenced by the rapid progress of information and communication technology. One of the information technologies that play a role in the world of education is online learning. Online learning functions as a relationship between lecturers and students with an internet network that can be accessed anytime and anywhere. The purpose of this study was to analyze the application of whatsapp based online learning combination in the class of employee, Program Study Information Technology, Universitas PGRI Madiun. This research method uses data collection methods, instruments used using questionnaires in the form of a list of questions aimed at employee class students. The results of the study concluded that $69 \%$ stated that learning was less effective conventionally, student interest in online learning was around $89 \%$ interested and $78 \%$ agreed that in its implementation it was considered more effective than conventional learning.
\end{abstract}

Keywords : online learning, learning model, student

\section{PENDAHULUAN}

Perkembangan Teknologi informasi di era digital sangat berpengaruh terhadap sistem pembelajaran yang ada sekarang, ditunjukkan dengan adanya pergeseran pembelajaran dari teacher centered learning menuju student centered learning. Sistem pembelajaran dulu masih menggunakan metode konvensional atau teacher centered learning dimana mahasiswa lebih banyak mendengarkan penjelasan dosen di depan kelas dan melaksanakan tugas jika dosen memberikan latihan soal kepada mahasiswa. Selain itu proses berbagi materi pembelajaran dilakukan dengan merekam dan menyalin ke flash disk dinilai kurang efektif dan efisien pada masa sekarang[1]. Salman Khan dalam bukunya "the one world schoolhouse" mengatakan bahwa pendidikan tidak terjadi di dalam ruang 
antara mulut dosen dan telinga murid, namun pendidikan terjadi di ruang dalam otak masing-masing[2]. Pernyataan salman khan sejalan dengan teori pembelajaran konstruktivisme dimana ilmu pengetahuan dibangun oleh murid melalui proses belajar, bukan dipindahkan dari dosen ke murid. Dengan adanya pernyataan tersebut semakin memperkuat adanya sistem pembelajaran Daring.

Pembelajaran Daring bertujuan memberikan layanan pembelajaran bermutu dalam jaringan (daring) yang bersifat masif dan terbuka untuk menjangkau peminat yang lebih banyak dan lebih luas [3]. Daring kombinasi adalah pembelajaran yang mengkombinasikan antara tatap muka dan daring. Daring kombinasi dilaksanakan dengan cara mempersiapkan sistem pembelajaran yang membutuhkan keterlibatan secara langsung antara mahasiswa dan dosen dalam proses pembelajaran. Dalam daring kombinasi pelaksanaan pembelajaran tidak dibatasi ruang dan waktu, yang tidak mewajibkan

\section{METODE}

Penelitian ini menggunakan metode pengumpulan data, Instrumen yang digunakan menggunakan kuesioner dalam bentuk daftar pertanyaan yang ditujukan kepada mahasiswa terkait dengan Pembelajaran Daring Kombinasi berbasis whatsapp pada kelas karyawan Prodi Teknik Informatika, Universitas PGRI Madiun. Analisis respon mahasiswa menggunakan skala guttman dalam bentuk checklist, dengan harapan didapatkan jawaban yang tegas mengenai data yang diperoleh. Tahap awal dari pembuatan kuesioner adalah mengumpulkan berbagai informasi yang ingin didapatkan dari responden yang kemudian dituangkan dalam kisi-kisi instrumen, setelah itu baru disusun pertanyaan dari kisi-kisi yang telah dibuat.

Pengujian validitas dilaksanakan dengan menelaah kisi-kisi instrumen sudah mahasiswa untuk selalu belajar di dalam ruang kelas dengan segala peraturan yang kaku [4].

Kelas karyawan prodi teknik informatika Universitas PGRI Madiun, mayoritas mahasiswanya merupakan pekerja yang harus membagi waktu untuk bekerja dan belajar. Hal tersebut membuat belajar tatap muka menjadi kurang efektif, karena cenderung motivasi belajar mahasiswa sudah menurun karena kecapekan dan mengantuk. Maka dari itu, pembelajaran daring kombinasi bisa menjadi solusi dan memberikan kemudahan dalam belajar.

Berdasarkan latar belakang masalah yang diuraikan, maka tujuan dari penelitian ini adalah; (1) Menganalisa tingkat keektifan kelas karyawan menggunakan metode konvensional (2) Menganalisa minat kelas karyawan menggunakan pembelajaran daring kombinasi (3) menganalisa tingkat keefektifan penerapan kelas karyawan menggunakan pembelajaran daring kombinasi.

sesuai dengan tujuan penelitian atau belum, selain itu juga menelaah kesesuaian alat ukur penelitian dan item-item pertanyaan yang diajukan terhadap responden. Setelah didapatkan data uji instrumen, dilakukan tabulasi pada tabel Guttman dengan menyusun item menurut ukuran skor jawaban "ya" tertinggi sampai terendah. Instrumen ini menggunakan kuesioner dengan skala guttman maka untuk memperoleh tikat validitas kuesioner, dilakukan perhitungan koefisen reprodubilitas dan koefisien skalabilitas. Adapun rumus untuk mengitung kedua koefisien adalah sebagai berikut: [5]

Koefisien reprodubilitas $(\mathrm{Kr})$

$$
K r=1-\frac{e}{n}
$$

Koefisien Skalabilitas (Ks) 


$$
\mathrm{Ks}=1-\left(\frac{e}{x}\right)
$$

Keterangan:

$\mathrm{Kr} \quad$ arti dari Koefisen Reprodubilitas

e arti dari Jumlah eror semua dari semua subjek

n arti dari Didapatkan dari perkalian antara jumlan subjek dan jumlah butir

Ks arti dari Koefisen Skalabilitas

$\mathrm{x}$ arti dari 0,5 (\{perkalian antara jumlan subjek dan jumlah butir \} skor)

Apabila hasil perhitunga $\mathrm{Kr}>0.90$ dan perhitungan Ks $>0.60$ maka item pernyataan dinyatakan valid

Sedangkan rumus yang digunakan dalam perhitungan untuk memperoleh persentase analisis tingkat keektifan kelas karyawan menggunakan metode konvensional, analisis minat kelas karyawan menggunakan pembelajaran daring kombinasi dan analisis tingkat keefektifan penerapan kelas karyawan menggunakan pembelajaran daring kombinasi terhadap kuesioner daring yaitu:[6]

Persentase $=\frac{\text { Jumlah skor total }}{\text { Skor kriterium }} \times 100 \%$

Skor kriterium $=$

skor tinggi tiap item $x \Sigma$ item $\mathrm{x} \Sigma$ responden
Berdasarkan persentase kriteria penilaian kuesioner daring, kuesioner daring dapat dikatakan layak apabila persentase dari respon peserta mencapai $\geq$ $61 \%$ dengan kriteria "Valid" atau "Sangat Valid"[6].

\section{HASIL DAN PEMBAHASAN}

Pada penelitian ini dihasilkan data dari penelitian dan pembahasan mengenai Pembelajaran Daring Kombinasi berbasis whatsapp pada kelas karyawan Prodi Teknik Informatika, Universitas PGRI Madiun.

Langkah awal yang dilakukan dalam menggunakan proses pembelajaran menggunakan daring kombinasi whatsapp grup adalah sebagai berikut:a. Membuat grup kelas di whatsapp dan mengundang semua anggota kelas tersebut b. Dosen dapat mengunggah materi pembelajaran dan tugas kuliah. File dan tugas materi dibagikan dengan akun kelas yang dibuat di whatsapp c. Mahasiswa bisa mengunduh materi dan tugas melalui akun mereka masing-masing. Mahasiswa juga dapat melakukan sesi konsultasi melalui grup whatsapp tersebut. Proses pembelajaran berlangsung selama 1 semester.

Setelah pembelajaran dengan metode daring kombinasi selesai dilaksanakan dalam satu semester, mahasiwa diminta mengisi kuesioner yang sudah disiapkan peneliti. Dari 18 soal kuesioner yang ada, 6 soal mewakili masing-masing aspek yang akan dianalisis, diantaranya, Analisis tingkat keefektifan kelas karyawan menggunakan metode konvensional, Analisis minat kelas karyawan menggunakan pembelajaran kombinasi dan Analisis penerapan kelas karyawan menggunakan pembelajaran daring kombinasi
A. Uji Validitas

Tabel 1. Tabel perhitungan Skala Guttman

\begin{tabular}{|c|c|c|c|c|c|c|c|c|c|c|c|c|c|c|c|c|c|c|c|c|}
\hline \multirow{2}{*}{ Responden } & \multicolumn{18}{|c|}{ Pernyataan } & \multirow{2}{*}{ skor } & \multirow{2}{*}{ error } \\
\hline & 1 & 2 & 3 & 4 & 5 & 6 & 7 & 8 & 9 & 10 & 11 & 12 & 13 & 14 & 15 & 16 & 17 & 18 & & \\
\hline 1 & 1 & 1 & 1 & 1 & 1 & 1 & 1 & 1 & 1 & 1 & 1 & 1 & 1 & 1 & 1 & 1 & 0 & 0 & 16 & 0 \\
\hline 2 & 1 & 1 & 1 & 1 & 1 & 1 & 1 & 0 & 0 & 0 & 1 & 1 & 1 & 1 & 0 & 0 & 0 & 0 & 11 & 0 \\
\hline 3 & 1 & 1 & 1 & 1 & 1 & 1 & 1 & 1 & 1 & 1 & 1 & 1 & 1 & 1 & 1 & 1 & 0 & 0 & 17 & 2 \\
\hline 4 & 1 & 1 & 1 & 1 & 1 & 1 & 1 & 0 & 0 & 0 & 1 & 1 & 1 & 1 & 1 & 0 & 0 & 0 & 13 & 0 \\
\hline 5 & 1 & 1 & 1 & 1 & 1 & 1 & 1 & 1 & J & cnal & $\mathrm{Nas}$ & oña & Pler & $d P d i$ & Kap - & $e k r$ & $i k^{0}$ & fop & atika & 83 \\
\hline SUM & 5 & 5 & 5 & 5 & 5 & 5 & 5 & 3 & 3 & 3 & 4 & 5 & 5 & 4 & 3 & 2 & 0 & 0 & 69 & 4 \\
\hline
\end{tabular}


Sebelum kuesioner disebarkan kepada mahasiswa/responden yang menjadi sampel dalam penelitian ini. Kuesioner terlebih dahulu diuji validitas. Kuesioner diuji validitas menggunakan skala untuk variabel tersebut baik untuk digunakan dalam survei.

$$
\begin{aligned}
\mathrm{Ks} & =1-\{\mathrm{e} / \mathrm{x}\} \\
& =1-\{4 / 0.5(90-69) \\
& =0.61
\end{aligned}
$$

\section{TINGKAT KEEFEKTIFAN KELAS KARYAWAN MENGGUNAKAN METODE PEMBELAJARAN KONVENSIONAL}

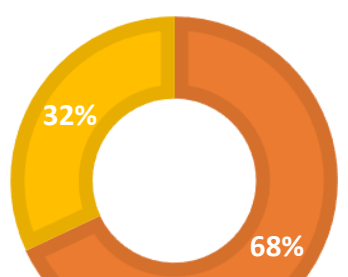

Gambar 1. Tingkat keefektifan kelas karyawan menggunakan metode pembelajaran konvensional

Gambar 2. minat kelas karyawan menggunakan pembelajaran kombinasi perhitungan skala guttman, uji validitas ini

\section{MINAT KELAS KARYAWAN MENGGUNAKAN PEMBELAJARAN KOMBINASI}

$$
\text { "ya } \text { - tidak }
$$

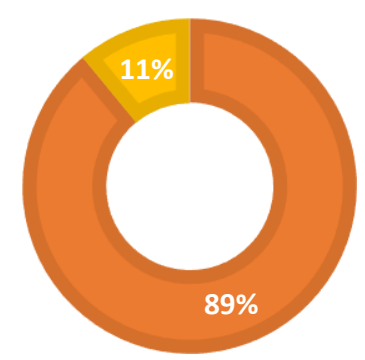

dilakukan kepada lima responden diluar dari responden yang dijadikan subjek penelitian, yaitu Dosen program studi teknik Informatika Universitas PGRI Madiun.

Tabel hasil perhitungannya dapat dibaca pada tabel1.

$$
\begin{aligned}
\mathrm{n}: & 5 \times 18=90 \\
\mathrm{Kr} & =1-\{\mathrm{e} / \mathrm{n}\} \\
& =1-\{4 / 90\} \\
& =0.955
\end{aligned}
$$

Dalam perhitungan ini terlihat bahwa $\mathrm{Kr}>0.90$, sehingga disimpulakn bahwa
Dalam perhitungan ini terlihat Ks> 0.60 , sehingga disimpulkan bahwa skala variabel tersebut baik untuk digunakan survei. Hasil perhitungan $\mathrm{Kr}$ dan $\mathrm{Ks}$ menunjukkan bahwa semua item pertanyaan adalah valid.
B. Analisis tingkat keefektifan kelas karyawan menggunakan metode pembelajaran konvensional


Setelah dilakukan pengumpulan data menggunakan kuesioner terhadap 13 orang mahasiswa kelas karyawan, maka hasil yang diperoleh adalah 68\% menyatakan bahwa metode konvensional dinilai kurang efektif dalam sistem pembelajaran dan $32 \%$ menyatakan efektif menggunakan metode pembelajaran konvensional. Hasil analisis tingkat keefektifan kelas karyawan menggunakan metode pembelajaran konvesional dapat dilihat pada gambar 1 .

C. Analisis minat kelas karyawan menggunakan pembelajaran kombinasi

Setelah dilakukan pengumpulan data menggunakan kuesioner terhadap 13 orang mahasiswa kelas karyawan, maka hasil yang diperoleh adalah $89 \%$ menyatakan berminat menggunakan pembelajaran daring kombinasi dan $11 \%$ tidak berminat menggunakan metode pembelajaran daring kombinasi. Hasil minat kelas karyawan menggunakan pembelajaran kombinasi dapat dilihat pada gambar 2 .

D. Analisis tingkat keefektifan penerapan kelas karyawan menggunakan pembelajaran daring kombinasi

Setelah dilakukan pengumpulan data menggunakan kuesioner terhadap 13 orang mahasiswa kelas karyawan, maka hasil yang diperoleh adalah $78 \%$ menyatakan penerapan kelas karyawan dengan metode

daring kombinasi sangat efektif dan $22 \%$ menyatakan penerapan kelas karyawan dengan metode daring kombinasi kurang efektif. Hasil Tingkat keefektifan penerapan kelas karyawan menggunakan pembelajaran daring dapat dilihat pada gambar 3.
Dari beberapa analisis yang sudah dilakukan maka bisa disimpulkan bahwa penerapan kelas menggunakan pembelajran daring kombinasi sejalan dengan pendapat Ni Putu Yuna Martika dalam jurnal yang berjudul "penerapan program guru pembelajar moda daring kombinasi terhadap peningkatan hasil uji kompetensi guru bahasa indonesia tingkat SMA di Kabupaten Gianyar" bahwa dalam daring kombinasi pelaksanaan pembelajaran tidak dibatasi ruang dan waktu, yang tidak mewajibkan mahasiswa untuk selalu belajar di dalam ruang kelas dengan segala peraturan yang kaku sehingga bisa melakukan pembelajaran dengan sistem daring kombinasi

\section{SIMPULAN}

Berdasarkan hasil penelitian yang sudah dilakukan, maka dapat disimpulkan bahwa:

a. Metode pembelajaran konvensional dinilai kurang efektif apabila diterapkan pada kelas karyawan prodi teknik informatika universitas PGRI Madiun, karena dalam kelas karyawan mayoritas mahasiswanya merupakan pekerja yang harus membagi waktu untuk bekerja dan belajar. Hal tersebut membuat belajar tatap muka menjadi kurang efektif, karena cenderung motivasi belajar mahasiswa sudah menurun karena kecapekan dan mengantuk.

b. Mahasiswa kelas karyawan prodi teknik informatika berminat mencoba menggunakan pembelajaran daring kombinasi

c. Metode pembelajaran daring kombinasi dinilai efektif apabila diterapkan pada kelas karyawan prodi teknik informatika universitas PGRI Madiun, karena dalam daring kombinasi pelaksanaan

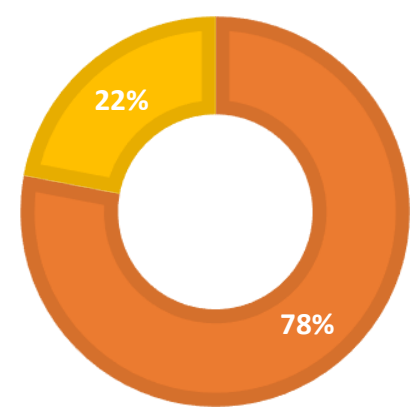


pembelajaran tidak dibatasi ruang dan waktu, yang tidak mewajibkan mahasiswa untuk selalu belajar di dalam ruang kelas dengan segala peraturan yang kaku.

\section{REFERENSI}

[1] Anardani. Sri dan Riyanto. Slamet. Using Cloud Storage to Improve Student Learning Motivation $n n$ Informatics Engineering University PGRI Madiun in Proc. ICONS, 2017, pp 12521257.

[2] Bilfaqih. Yusuf, Qomarudin. M. Nur. Esensi Pengembangan Pembelajaran Daring. Sleman: deepublish, 2015

[3] Adhe. Kartika. R. Model Pembelajaran Daring Matakuliah Kajian PAUD di Jurusan PG PAUD Fakultas IImu Pendidikan Universitas Negeri Surabaya. Journal of early childhood care \& education, 2018:vol. 1 No. 1 , hal 26-31,

[4] Martika. Ni. Putu. Penerapan Program Guru Pembelajar Moda Daring Kombinasi Terhadap Peningkatan Hasil Uji Kompetensi Guru Bahasa Indonesia Tingkat SMA Di Kabupaten Gianyar. eJournal Jurusan Pendidikan Bahasa dan Sastra Indonesia, 2018: Vol. 7 No. 2.

[5] Saifudin. A. Reliabilitas dan Validitas.Yogyakarta: Pustaka Belajar. 1997

[6] Fendya. Wimona $\mathrm{T}$ dan Wibawa. Sendra C. Pengembangan Sistem Kuesioner Daring dengan Metode Weight Product untuk Mengetahui Kepuasan Pendidikan Komputer pada LPK Cyber Computer. Jurnal IT-EDU. 2018:Vol 03 No 01. pp 45-53. 